\title{
[Chorus:] Television, the drug of the Nation...
}

\section{Szerzői információ:}

$\mathrm{H}$ a m m e r Ferenc

Tànársegéd az ELTE Mũvészetelméleti és Médiakutatási Intézetében. 2002-ben a Nyílt Társadalom Intézet (OSI) - CEU Center for Policy Studies International Policy Fellowship programjának ösztöndíjasa. A közeljövő́ben jelenik meg monográfiája az RTL Klub Fókusz c. músorának szegénységábrázolásáról.

Így hivatkozzon erre a cikkre:

Hammer Ferenc. „[Chorus:] Television, the drug of the Nation...”.

Információs Társadalom IV, 3-4. szám (2004): 51-55.

—https://dx.doi.org/10.22503/inftars.IV.2004.3-4.8

A folyóiratban közölt müvek

a Creative Commons Nevezd meg! - Ne add el! - Így add tovább! 4.0

Nemzetközi Licenc feltételeinek megfelelően használhatók. 
$\mathrm{H}$ a $\mathrm{mmer}$ Fer e n c

[Chorus:] Television, the drug of the Nation...

„T.V., is it the reflector or the director?

Does it imitate us

or do we imitate it

because a child watches 1500 murders before he's twelve years old and we wonder why we've created

a Jason generation that learns to laugh rather than to abhor the horror

T.V. is the place where

armchair generals and quarterbacks can

experience first hand

the excitement of warfare

as the theme song is sung in the background

Sugar sweet sitcoms

that leave us with a bad actor taste while pop stars metamorphosize into soda pop stars

You saw the video

You heard the soundtrack

Well now go buy the soft drink

Well, the onla cola that I support

would be a union C.O.L.A.(Cost Of Living Allowance)

On television

[Chorus:]

Television, the drug of the Nation

Breeding ignorance and feeding radiation

(Repeat)“

Disposable Heroes Of Hiphoprisy

Jelen bírálat tartalma és formája között fennáll egy összefüggés. Ez a bírálat meglehetôsen kurta, és kissé hevenyészett is. Ennek oka az, hogy az elmúlt hétvégén, amikor lett volna alkalmam elkészíteni ezt a munkát, az idômet mással töltöttem. Egyrészt százegynéhány magammal a Ráckertben voltam, különös tekintettel a csehdán meccsre. Ezen eseménnyel kapcsolatban talán nem érdektelen megjegyezni, hogy az elsố félidő lelketlen labdatologatásáért bốven kárpótolt a második félidô elsô húsz perce; Milan Baros első gólja láttán még a szemmel láthatóan alkalmi focinézők is lelkesen hejehujáztak. Miklós tételét valószínúleg teljesen pontosan igazolta a ráckerti tapasztalat; a közönség fejében kibogozhatatlanul összekeveredett a látszat és a valóság (a genius loci és a mediatizált tapasztalat), ugyanis a mérkőzés befejeztével tapsviharban tört ki a kivetítő elôtt ülő tömeg: bistosan elkábulva ast hitték, hogy Portugáliában vannak. A közösségi meccsnézés mellett pedig horgásztam. Erről a dolo- 
gról a kívülállónak azt kell tudni, hogy a Balatonon éjszaka, négyszáz méterre a parttól, órákon keresztül ülni egy igen kicsi csónakban nem könnyư dolog. Az is megjegyzendő, hogy hazánkban a Magyar Országos Horgász Szövetség a legnagyobb létszámú társadalmi szervezet (324 ezer tagja van). Összefoglalva tehát, azért nem tudtam a média által gerjesztett ökocídiumról szóló tanulmány bírálatára alaposabban felkészülni, mert egyrészt radikálisan offline voltam, másrészt pedig egy médiaesemény résztvevőjjeként töltöttem egy kellemes estét barátaimmal. Amúgy szombat éjszaka elég különös angolnát fogtam (testhossza $62 \mathrm{~cm}$ ), ugyanis egyáltalán nem volt jobb szeme. A fiam szólt, hogy egyszemű az angolna, és először azt hittem, hogy akkor veszthette el a szemét, amikor egy fahasábbal agyonvertem. De nem, szemürege sem volt neki; elég ijesztố volt.

Röviden szólva eléggé a falra másztam Miklós szövegétől. Sommásan, szerintem egy helyes célhoz választott egy helytelen eszközt. A cél helyes, mert az ökológia, jobb szót nem találok rá, egyszerúen metafizikai kérdés. Viszont a médiatudományból/médiaelméletből mint megismerési eszközből a cél érdekében huszártrombitát csinálni helytelen, káros és bűnös dolog. Ha a cél a közfigyelem felkeltése, ami helyes dolog, akkor arra valami olyan eszközt kéne alkalmazni, amit erre találtak ki, például a politikát, az oktatást, a médiát, a múvészetet, a személyes példaadást stb., de a társadalomtudományt ebbe nem kéne belerángatni. (Ezzel nem azt akarom mondani (sốt...), hogy a normáknak nincs köze a társadalomtudományhoz, hanem azt, hogy nem így van köze.) Egyszer írtam valahol, hogy a moralizálást az különbözteti meg a nem moralizálástól, hogy ajánl, vagy tesz valamit, ami révén a felvázolt probléma, ha minimálisan is, de csökkenhet. Például ebben az esetben lehetne úgy forgatni a szót, hogy kiderüljön, lehetséges az ökológiai szempontokat mint közérdek-problémát elismertetni, mert ettől kezdve másképpen esne latba a társadalompolitikában (így a médiaszabályozásban is; N.B. erre van már példa: a „határok nélküli televíziózásról” szóló EGK irányelv, amit a legnagyobb rosszindulattal sem nevezhetünk aktivista tartalomszabályozási dokumentumnak, csekély számú tartalmi tiltásai között tartalmazza azt, hogy a természet pusztítására sem kiskorúaknak szóló program, sem pedig reklám nem buzdíthat.) Pontokba szedve, kissé hevenyészett széljegyzetek következnek most. Néhol egy kicsit gúnyolódom, de kérem Miklóst, ne szívja mellre.

1. Dányi, Dessewffy, Karvalics, Pintér stb. kollégák érveihez csatlakozva úgy vélem, hogy a modernitáskritikát médiaszapulássá redukálni egyszerúen nonszensz. Körülbelül úgy jár el Miklós, mint ha valakit megkérdeznének, miért kellett meghalnia Giordano Brunónak, akkor a válaszban részletes leírást kapnánk egy csomó fahasábról, illetve azok nedvességtartalmáról és elhelyezkedéséról, különös tekintettel Bruno létfontosságú szerveire.

2. Amúgy pedig még ez a hasonlat is sántít, hiszen az ökocídium jelentős részét már akkor végrehajtották, mielốtt még bárki akár csak a Szokol rádióról is hallott volna harangozni. Ha így vesszük, ki lehet számolni, hány tiszai ciánmérgezéssel ért fel a Tisza XIX. századi szabályozása. Amúgy pedig némileg fellengzôsen úgy is mondhatnám, hogy amennyiben a körülöttünk lévô természetet tekinthetjük örökségként (erre utal is egy öko-szlogen), akkor Ézsau döntésének öko-változata úgy szólhatna, hogy az ember (amennyiben 
megvoltak hozzá az eszközei) a legutóbbi időkig következetesen mindig feláldozta természeti környezetét az anyagi gyarapodás vagy egyszerủen a túlélés érdekében, legyen szó mammutokról, ókori mediterrán erdőkrôl, a nemeai oroszlánról vagy hortobágyi túzokokról.

3. Amennyiben a tudatos kétkezi természetpusztítást is természetpusztításnak tekintjük (gyomirtózás, malacdopping, vakondvadászat, vegyszeres szúnyogirtás, rapsickodás, illegális hulladékbányák stb.), akkor feltûnhet, hogy ezt nagyobbrészt a kevesebb médiát fogyasztó lakosság követi el. Az erdélyi havasok erdőit nem hiszem, hogy tévé- és/vagy Internet-függố véglények vágják ki illegálisan építőanyagnak. Ha a parasztokon múlna, az egész országot lebetonoznák disznóólnak, sốt meggyőződésem: a magyar lakosság túlnyomó része (függetlenül lakhelyétốl) anyagi érdekbôl bármikor hajlandó lenne aktív vagy kényelmességból elkövetett természetkárosításra (kedvenceim például az olasz madár-tömeggyilkosoknak asszisztáló vadőrök), viszont a környezettudatosság igenis (mediatizáltabb) városi vircsaft (vagy legalábbis onnan indult).

4. Fontos beszélni arról, hogyan tudtak több generációval ezelőtti paraszti közösségben úgy gazdálkodni, hogy ne tegyék tönkre a környezetüket. Azonban ebbôl szinte semmi nem következik a mi életünkre nézve. Mindenekelôtt azért, mert ez a föld szeretetén alapuló életszemlélet egyszersmind jelentett mániákus földéhséget, és olyan mondásokat, hogy „a föld nem szereti az egyenes derekat", továbbá jelentette azt a tekintélyelvư és embernyomorító kultúrát is, amiben minden számított, csak az ember ideje, akarata, méltósága nem (lásd Móriczot, Szabó Zoltánt vagy Illyést).

5. Ezt a pontot kibôvítve utalnék arra, hogy a környezettudatosságot is a modernitás találta ki (arról nem is szólva, hogy magát a természetet is: lásd romantika, stb.) Miklós tanulmányával szemben felhozott két fő érvem egyike az, hogy az ökológiát egyfajta újszerû reflexivitásnak, érzékenységnek tekintem, mivel a közvetlen haszna (például a szelektív hulladékgyưjtés esetében) nem feltétlenül látszik az életvilágban (ezért nem tekintem a földet okosan nem kiszipolyozó természeti kultúrákat ökológiailag releváns tapasztalatnak, mivel ha nem úgy tennének, néhány éven belül éhen halnának). Ily módon az ökológiai gondolat mint újszerû reflexivitás egy elképzelt megsebzett világot életre álmodó gondolat (olyasféle civic religion, mint az alkotmányosság tisztelete), viszont a reflexivitás ügyét (ld. Urry-Lash: Economies of Time and Space) ellentétbe állítani a média-, illetve IKT-fogyasztással akkora bûvészmutatvány, amit én nem tudok követni.

6. Miklós írja: „A Föld véges ökológiai rendszerében végtelen gazdasági növekedés nem lehetséges." Tekintettel arra, hogy Miklós sem konyít a makroökonómiához, én sem teszek úgy, mintha értenék hozzá. Egyrészt azért azt megjegyezném, hogy az ökológiát ma az érdekeltek többnyire fogyasztás révén teszik életük részévé, másrészt pedig felhívnám a figyelmet arra, hogy 100 és 101 között végtelen sok szám található. 
7. A tanulmánnyal szemben a másik fó érvem az, hogy a dolgozat egyik pillérét, a „valódi” és a mediális (elképzelt??) tapasztalat szembeállítását semmilyen körülmények között nem tartom elfogadhatónak. Kérem, senki ne tekintse felfuvalkodottságnak, de azt gondolom, ezt nem kell megindokolnom. Mentőötletként javaslom, hogy a szövegen még vadítanék egy kicsit, és tudományparódiaként közölném mint Ferdinand Tönnies lappangó kéziratát a televízióról 1902-ből.

8. Miklós írja bánatosan, hogy „a 20. század derekától folyamatosan nô a médiavalóságra fordított tudatos és tudattalan figyelem, a médiavalóságban töltött idő." Innen nézve ez tûnhet ijesztőnek, ám ne felejtsük el, 50 vagy 100 éve még mennyire örültek annak, hogy egyre kevesebb embernek kell manuálisfizikai munkát végezni, mert akkor azt tekintették az ember elállatiasításának. Most meg mást mondunk szörnyúnek.

9. A médiahatásokkal kapcsolatos fejtegetések tendenciózusan szelektívek. Például Miklós ezt írja: „Az egymástól fizikai és szimbolikus térben egyaránt távoli témák egymás utánivá rendelése, sorbaállítása logikus, biztonságos rend és valóság képzetét kelti." Gerbner, akinek kulcsszerepe volt abban, hogy az (amúgy szerintem kétes érvényư) „egylépéses” médiahatások a közbeszéd és a policy részévé váltak, ennek pont az ellenkezôjét mondja. Ez a baj az aktivista médiadiskurzussal, hogy mindig úgy forgatja a megismerés fókuszát, hogy az látszódjon belőle, ami beleillik a képbe, és közben pont a megismerés az, ami egyre kevésbé fontosabb.

10. Miklós írja: „a megsokszorozott médiaélmény függốséget okoz.” A heroin és a cigaretta, na az igen.

11. Az ökológia válsággal kapcsolatos médiahallgatás rövid elemzése ígéretes része a tanulmánynak.

12. Miklós írja: „Az odavezetés (a reklámhoz), az elvezetés (a természeti környezettől) és az élveztetés (a fogyasztásra irányuló meggyôzố kommunikáció) egymást feltételező, párhuzamos folyamatok." Lennének, mondhatnánk, ha a köznyelv (szemben e jeremiádával) értelmes fogalomnak tekintené azt a szót, hogy „élveztetés”. Az nem véletlen, hogy ilyen szó nincsen.

13. Miklós írja: „Egyre riadtabban és gyámoltalanabbul álldogálunk életünk terében...” Bírálatom első, magánlevél-változatában itt azt írtam: „Ha lesz egy ,rohanó világunkban', abbahagyom az olvasást." Most sem tudok mást írni.

14. A reklámokról szóló rész szerintem kilóg a tanulmányból, mivel a kedélytelen pszichologizmusokon túl nem ajánl érveket megfontolásra. 
15. E bírálat elején azt írtam, hogy társadalomtudománynak álcázni ezt a nagylöttyös médiakritikai aktivizmust helytelen, káros és bûnös dolog. Azért helytelen, mert a röviden említett fogalmi nonszenszek mellett kérdés, hogy a tanulmány kapcsán miről is beszélünk. Az már egy kicsit bonyolultabb kérdés, hogy miért káros ez a szöveg. Ehhez fontosnak tartom leszögezni, hogy ez az egész vita nem jöhetett volna létre, ha ezt a szöveget nem Sükösd Miklós, sokunk kipróbált harcostársa, kollégája, barátja készíti el.

Talán nem járok túl messze a valóságtól, ha azt feltételezem, a recenzensek többsége nemhogy nem írta volna meg véleményét, de végig sem olvasta volna a dolgozatot, ha nem Miklós küldi. Így viszont egyre dagad a vita, rajta van az IT'TK-honlapon, megjelenik könyvben, és a vitában az egyik oldalon a médiakritika-mozgalmárok vannak, a másik oldalon a szakma, azaz egy újabb ritualizált adok-kapok alakul ki, ami az egyik legfontosabb akadálya annak, hogy a (kereskedelmi) médiában változást egyedül generálni képes, kölcsönös belátáson alapuló önszabályozó kultúra kialakuljon. Egy másik helyen ezt így mondtam: „...ha a tévéellenes hisztéria domináns a tévé tevékenységét mérlegre tevó közbeszédben (amire valóban legjobb, ha vígan legyintenek a kereskedelmi televíziók), akkor egyre kisebb lesz az esély arra, hogy be lehet tartatni a valóban fontos szabályokat." Lehet, hogy ez csak nekem a vesszôparipám, de azért ütött szíven ez a munka, mert fontosnak tartom, hogy a népi-mozgalmi „médiaelméleteket” el lehessen különíteni a szakmától és a tudománytól. Miklós összekapcsolja óket, amiért egy kicsit talán haragszom is rá. Végül pedig azért tekintem bünösnek ezt a munkát, mert a nyilvánosság révén emberekben megerősödhet az elképzelés, hogy az efféle, az embert döntésre képtelen áldozatnak tekintő beszédmód a médiáról és a társadalomról helyes és követendő dolog.

16. Ökológiai tárgyú, bármilyen jellegû́ médiakutatásban nagy kedvvel és lelkesedéssel vennék részt Miklóssal vagy másokkal. 